LONDON-Britain's major biotechnology company, Celltech Ltd., is seeking to increase its presence abroad. With some 90 percent of its sales already coming from outside the U.K., Celltech (Slough, U.K.) has formed an American subsidiary. Actually owned by the Boots-Celltech Dragnostics Ltd. joint venture in Slough, the newly operational company is called Boots-Celltech Diagnostics Inc. Located in Morristown, NJ, the spin-off will focus on marketing its parent company's diagnostic products in the U.S. Although Boots-Celltech Diagnostic Ltd. currently registers only 10 percent of its sales in the U.S., Celltech chief executive Gerard Fairtlough predicts that this figure could increase to close to 50 percent within a year.

"The U.S. is usually where things start, and then the world learns from it," explains Fairtlough. "The trends in world healthcare start in the U.S., and if you're not linked into it, you're in danger of not being on target...We are going to have a very strong U.S. identity." Fairtlough notes that Celltech already has a track record with spin-offs - the company also maintains a joint venture with Air Products called Apcel.

\section{The U.S. Subsidiary}

Boots-Celltech's American subsidiary, which is headed by former American Hospital Supply executive W. Barry McDonald, will begin operations by marketing three monoclonal antibody-based products: diagnostic tests for chlamydia, respiratory syncytial virus, and thyroid stimulating hormone. Three other hormone assays have been submitted for approval to the U.S. Food and Drug Administration. Although the American start-up only has three employees at present, its plan calls for a staff of $10-15$ by the end of the year. Marketing is clearly the number-one priority, but Fairtlough notes that the future could hold opportunities for U.S.-based development work and production, as well as, eventually, research. Concludes Fairtlough: "We believe that Boots-Celltech Diagnostics Inc. is poised to hit the U.S. market in a big way." The British executive adds that if this first American foray is successful, he foresees the possibility early next year of forming a similar U.S. operation for Celltech's cell products manufacturing business.

Taking a page out of the financing strategies followed by many American start-ups, Boots-Celltech Diagnostics Inc. will soon be offering equity to three groups: its management, an as yet undetermined healthcare company that has relevant physical facilities, and an investment bank. Fairtlough says that this private financing should be completed by the end of this year, and that a public offering is possible later.

\section{The Parent Company's Progress}

Celltech Ltd. is also looking ahead toward the public market. In addressing the Fourth Annual Hambrecht and Quist Health Care Conference, held in San Francisco during January, Fairtlough stated that Celltech would like to be "in a position to be able to go public" around the middle of 1987. Such an offering would most probably take place on the London exchange. Now earning revenues on a small number of products it has already brought to the market, Celltech Ltd. seems set to attain profitability by 1987 . The company's 1985 results, published recently, reveal a turnover of some $£ 3.8$ million, compared with $£ 1.9$ million the previous year. Its losses (reflecting heavy investment in new developments, but also sales of know-how to Apcel) have been cut from $£ 1.9$ million to about $£ 1.4$ million over the same period. Last year, the company spent about $£ 2.5$ million developing its own products, and an additional $£ 1.5$ million on contract work for customers. The Boots-Celltech partnership turned a 1984 deficit into a $£ 1$ million profit.

Formed in 1980 on the initiative of the National Enterprise Board, Celltech's shareholders now include the British Technology Group, Prudential Assurance, and British \& Commonwealth Shipping. The FDA recently licensed the company's manufacturing plant for the bulk culture of monoclonal antibodies in a 1000-liter deep-tank fermentor; concurrently, Celltech signed an agreement with Ortho Diagnostics (Raritan, NJ) for the manufacture and sale of bloodgrouping reagents.

Introducing Celltech's 1985 annual report, chairman John Jackson revealed that collaboration with Sankyo on calcitonin and tissue plasminogen activator is now nearing the end of its development stage and approaching scale-up and production of pharmaceutical-grade material for clinical trials. In addition, the "authentic" recombinant human growth hor- mone that Celltech scaled up for Serono has now made it to clinical trials.

\section{New Estrus Test}

Boots-Celltech Diagnostics, which now boasts 10 kits on sale, recently announced that it has developed a rapid test to indicate when dairy cows come into sexual heat. An ingenious monoclonal antibody application evolved by Terry Baker and his colleagues, the kit will be manufactured by Bayer AG and is expected to go on sale in the middle of this year. The West German company will market it worldwide, except in China and Japan (where it will be distributed through Sumihito Corp. in collaboration with Sankyo).

An accurate knowledge of estrus is important for two closely related reasons: the timing of artificial insemination and the maintenance of maximum milk production. A cow must calve every 365 days if it is to continue producing large quantities of milk, so any time lost thereafter represents a financial loss- -11 per day in Britain. Moreover, opportunities for successful insemination occur only every three weeks, when progesterone levels are at their lowest.

Unlike previous techniques, which require milk to be taken away for assay in the laboratory, the new method is a "cow-side test" that can be used by farmers in the milking parlor. This reduces the chance that vital time will be lost and the opportune moment missed. Developed in association with scientists at Celltech and University College (Cardiff), the test is based on the milk-clotting enzyme chymosin, a monoclonal antibody to progesterone, and an inhibitor of chymosin labeled with progesterone. The farmer simply adds a little of the cow's milk to a tube containing these freeze-dried reagents. If there is little or no progesterone in the sample, the antibody will bind to the enzyme inhibitor, causing the milk to clot within 30-60 minutes. If progesterone is present, however, the milk stays unchanged because the inhibitor remains free.

As there are some 60 million dairy cows throughout the world, BootsCelltech estimates the total value of markets for the test at $£ 45$ million. Now undergoing field trials, the kit may also prove valuable for confirming pregnancy and monitoring an animal's response to the induction of estrus. -Bernard Dixon and Arthur Klausner 